\title{
Message on Slogan Material Published Through Instagram Class VIII Tolerance Junior High School Joannes Bosco Yogyakarta 2018/2019
}

\author{
Angela Reni Suryoresmi* \\ Indonesian Language and Literature Education of \\ Graduate School \\ Universitas Negeri Yogyakarta \\ Yogyakarta, Indonesia \\ suryoresmi@gmail.com
}

\author{
Kastam Syamsi \\ Indonesian Language and Literature Education of \\ Graduate School \\ Universitas Negeri Yogyakarta \\ Yogyakarta, Indonesia \\ kastam@uny.ac.id
}

\begin{abstract}
This study contains the use of smart phone applications in the learning process at Joannes Bosco Middle School. The author has conducted a survey of Joannes Bosco Middle School students by using a questionnaire and observation of students, the authors see that students use smart ponsel to communicate, discuss, and complete their assignments. Therefore, as an Indonesian teacher, the writer uses this opportunity to use social media, in this case Instagram, as a means of publication about class VIII Tolerance slogans at Joannes Bosco Middle School. The purpose of this study is to introduce students to use media in learning.
\end{abstract}

Keywords-Message, slogan, media, learning

\section{INTRODUCTION}

Schools at this time are changing many patterns of teaching and publications related to the material presented. This is of course related to the behavior of teenage students who are very close to the internet. Tapscott (2009:11-16) explained that the current generation using the internet is divided into four namely: the first generation of baby booms born in January 1946December 1964, the second generation X born in January 1965- December 1976), the third generation Y born January 1977- December 1997 and the fourth generation $\mathrm{Z}$ who was born in January 1998 until now or is called millennial generation. Not only research conducted in America but also this pattern of development has been followed by various countries throughout the world including Indonesia.

\section{METHOD}

Teenagers in Indonesia at this time are very familiar with devices/smart phones. Based on our small research through small polling by questions for every student, every teenager spends their time using Instagram or WA media (WhatsApp) for six to eight hours a day or even 24 hours. Every morning the children used to open their devices after waking up. After that, they just started doing activities as usual. Every day these teenage students use smart phones to communicate and discuss work on schoolwork. This dependency encourages schools to conduct research. In a small study using the questionnaire / questioner or polling method to students of Joannes Bosco Yogyakarta Middle School, they use their phone over time. Eriyanto (1999:75-76) defines polling as a systematic way to gather information from samples which are then used to generalize populations. The description of student data acquisition and interpretation can be described as follows.

\section{RESULT AND DISCUSSION}

A. Student Poll Results Description Of Student Questionary Data In Using The Smart Phoneat the Joannes Bosco Junior Middle School Yogyakarta Yearof 2018/2019

Based on data obtained $90 \%$ of students have used a device for more than two years, while another $10 \%$ have been less than two years. Most students get adequate facilities from parents by having a personal device as much as $30 \%$ while another $70 \%$ use the device with their parents. Some students are able to manage the use of devices, $50 \%$ of students use 3-5 hours per day, $20 \%$ of students use devices between 1-2 hours, $30 \%$ of students use devices more than 7 hours. Students are not optimally using the you tube application for self-development $60 \%$ of students watch movies, $100 \%$ listen to music, $40 \%$ look for general news, $55 \%$ look for specific info, $55 \%$ use several times to find information, $40 \%$ occasionally use you tube to looking for information, $55 \%$ is used to work on tasks, $40 \%$ is used for information and doing work. Students do not yet understand how to use a device used to develop interests and talents $32.4 \%$ use a device to float musical talent, $25.4 \%$ use a device to develop sports talent, $6.5 \%$ a device is used to develop game talent, while the rest is for another talent. Photos / content that have been uploaded are favorite media $82 \%$ photos, $50.8 \%$ videos, $28 \%$ songs, $14 \%$ subject matter, $15 \%$ funny things.

Based on these data and interpretations, data is obtained that the dependence of smart phones is very high, so schools also utilize the role of smart phones in learning in schools. Livingstone (2004: 3-5) explains that media literacy includes media access, media analysis and evaluation. So, as Indonesian language teachers, they must be able to take advantages of opportunities to use the media used by these children in learningand one of the materials is slogan advertisement materials in class VIII according to the syllabus in the national education service curriculum. Terry Flew (2002: 10) provides an 
explanation that the new media can be used as a form or content of media that is combined and integrated in a digital format in the form of data, text, images or the like that is published through a network in this case the internet. DeVito (2015: 7) revealed that effective communication is not only built because of closeness but if the communicator can provide and receive messages from one another. So, the teacher takes the initiative to be able to use media that are familiar with adolescents so that the material can be well received. If students are not allowed to use devices, what they feel is (1) they feel they are not considered friends, (2) they feel incomplete, (3) their communication is interrupted because everything is communicated through wa (whats app), (4) they feel they are assigned many school staff are left behind because sometimes class discussions to discuss homework are done using wa, (5) very uncomfortable because they cannot communicate at the same time cannot follow the progress of class assignments.

Friends are still the dominant choice in social media because there are always friends to chat, develop potential with friends, have many friends with social media. The bad thing about internet addiction to games and social media has a negative effect: $22.5 \%$ pornography, $39 \%$ rough speech, $47.6 \%$ social addiction, 57.8 hoaks, 29.9 bullying / violence, $11.2 \%$ consumerism, $16,6 \%$ religious heresy, $35.8 \%$ addicted to games.

Bad habits obtained from the use of the internet from gadgets in freedom of speech that are not polite, being alone due to gadgets are also noteworthy, $33.3 \%$ are addicted to pornography, $34.1 \%$ are rude speech habits, $11.5 \%$ are easy to spread the news, $4,9 \%$ easy to bully / violence, $29.1 \%$ are addicted to buying goods, $30.2 \%$ are involved, $23.6 \%$ believe in wrong information, $19.8 \%$ consider other things unimportant.

Table 1.

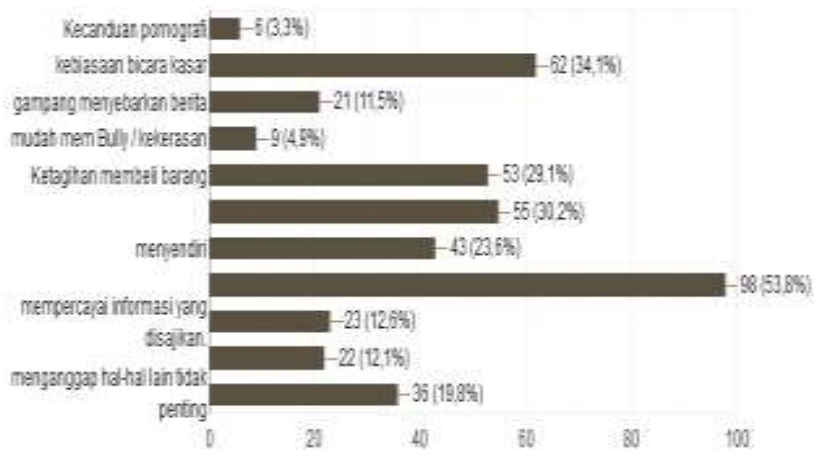

The involvement of parents in giving advice to students related to the device shows positive and negative respect, $50 \%$ of parents advise, $40 \%$ do not care, $45 \%$ are advised and listened in relation to the use of online games. Learning while playing a gadget $65 \%$ advise, $70 \%$ are advised and listened to, $25 \%$ don't care. Some students respect their parents and still make them idols related to the use of devices $99.9 \%$ respect and love parents, $0.01 \%$ doubt parents because parents are busy with their devices.

\section{B. Application of Slogan Material on Instagram}

The material written in presents ideas, messages, solicitation in the form of advertisements, slogans, or posters orally with indicators make ideas, messages, invitations in the form of advertisements, slogans, or posters verbally and in writing, learning materials on how to compose ad text, slogans, posters, while the learning activities are Writing ads, slogans, or posters based on the context that has been formulated is presenting advertisements, slogans and / or posters written in various variations.

In this case students get teacher guidance to write slogans with the theme of utilizing media for learning. The steps taken by the teacher are by explaining the students in class about slogan material. The slogan according to KBBI V is interesting or striking short words or sentences that are easy to remember to notify or advertise something like Solo Berseri (clean, healthy, neat) or short sentences that are interesting, striking and easy to remember to explain the goals of a group, organization, ideology political parties and so on. This material gives students lessons about advice or instructions for doing the right thing. The theme presented is in accordance with the world of the students, hence, easy to remember by students. This slogan material included pictures and writing so that it is easy for students to remember. This material was made in digital form, one picture was made by two students. The number of students in class VIII Tolerance is twenty students, so the number of slogans obtained is ten pictures. The image after it will be posted on the class Instagram can be seen by anyone who accesses it. Instagram was chosen because it contains pictures and short writing that is easy for students to read. This is eassier for the students because the task of using a smart phone is easily accessible to students.

\begin{tabular}{|l|l|}
\hline & 2. Gunakan dan \\
\hline 1. Jalan-jalan ke & Teknologi dengan Bijak. \\
Yogyakarta, katanya & (2. Use and Technology \\
kota pelajar, Susan & Wisely) \\
Payah belajar kelak & \\
agar menjadi pintar. & \\
(1. Travel to Yogyakarta \\
They say the city of \\
students, Study hard \\
in order to be smart $)$
\end{tabular}




\begin{tabular}{|c|c|}
\hline 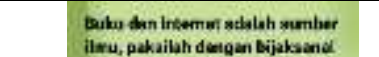 & 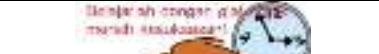 \\
\hline $\begin{array}{l}\text { 2. Buku dan internet } \\
\text { sumber ilmu, pakailah } \\
\text { dengan bijaksana. } \\
\text { (2. Books and internet are } \\
\text { the sources of } \\
\text { knowledge, use them } \\
\text { wisely) }\end{array}$ & $\begin{array}{l}\text { 3. Belajarlah dengan } \\
\text { giat untuk meraih } \\
\text { kesuksesan. } \\
\text { (3. Study hard to achieve } \\
\text { success) }\end{array}$ \\
\hline & 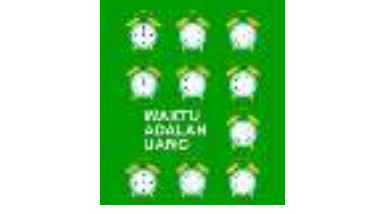 \\
\hline $\begin{array}{l}\text { 4. Aturlah waktu sebaik } \\
\text { mungkin dalam } \\
\text { kehidupan! } \\
\text { (4. Arrange the best time } \\
\text { in life!) }\end{array}$ & $\begin{array}{l}\text { 5. Waktu adalah uang. } \\
\text { (5. Time is money) }\end{array}$ \\
\hline $\begin{array}{c}\text { ATURLAH } \\
\text { WAKTU } \\
\text { SEBAIK } \\
\text { MUKGKIN! }\end{array}$ & BUAK \\
\hline $\begin{array}{l}\text { 6. Aturlah waktu sebaik } \\
\text { mungkin. } \\
\text { (6. Arrange your time as } \\
\text { good as possible) }\end{array}$ & $\begin{array}{l}\text { 7. Gunakan waktu dan } \\
\text { teknologi dengan } \\
\text { bijak! (Use your time } \\
\text { and technology } \\
\text { wisely!) }\end{array}$ \\
\hline
\end{tabular}

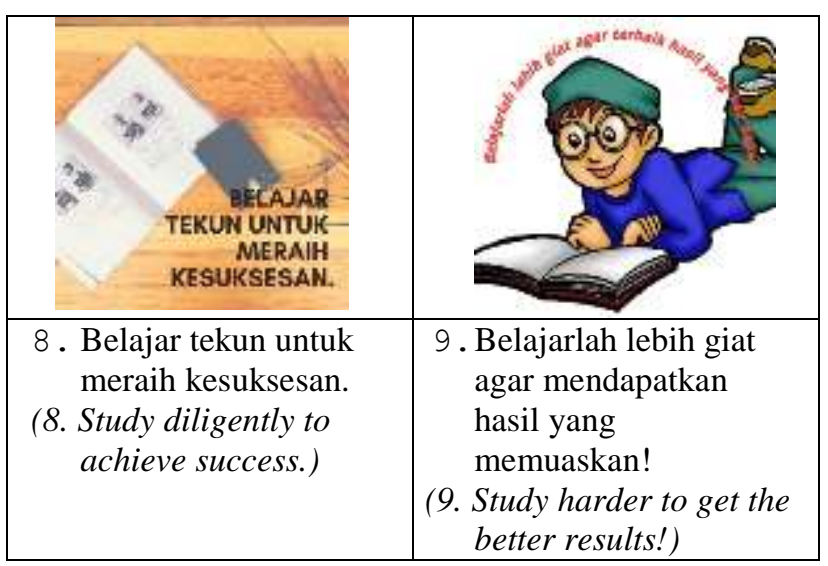

Figure 1. Example of images

\section{CONCLUSION}

The enthusiasm of using a smart phone encourages students to work on assignments digitally. The examples above are the results of assignments published through instagram media that are familiar to students. The messages conveyed are also advice that needs to remind students of some things that must be considered. This is more effective for students today because the use of digital technology that can be accessed via smart phones is so easy in today's digital era.

\section{REFERENCES}

DeVito, Joseph. A. (2015). Human Communication. The Basic Course. Thirteenth Edition. USA: Pearson Education.

Eriyanto. (1999). Metodologi Polling. Bandung: PT. Remaja Rosdakarya Flew, T. (2002). New Media: an Introduction. Malbourne: Oxford University Press.

Livingstone, S. (2004). Media literacy and the challenge of new information and communication technologies.

Communication Review, 1 (7), 3-14.

Tapscott, D. (2009) Grown up digital: How The Net Generation Is Changing Your World. New York, US: McGraw-Hill. https://kbbi.kemendikbud.go.id. 2019.07.19.00.23. 